\title{
多段分級式粒度及び濃度自動測定装置の開発
}

\author{
小野 哲 夫*, 小谷田 一 男*, 牧 野 尚夫*, 洪 公 弘** \\ 斉藤和 男**, 渡辺金之助 ${ }^{* *}$, 井伊谷 鋼一***
}

\section{Development of an On-line Measuring Apparatus of Particle Size Distribution and Concentration with a Three-stage Classifier}

by

\author{
Tetsuo $\mathrm{ONO}^{\dagger}$, Kazuo KOYATA ${ }^{\dagger}$, Hisao MAKINO ${ }^{\dagger}$, G. H. $\mathrm{HONG}^{\dagger \dagger}$ \\ Kazuo SAITO ${ }^{\dagger \dagger}$, Kinnosuke WATANABE ${ }^{\dagger \dagger}$ and Koichi IINOYA ${ }^{\dagger \dagger}$
}

It is very important to measure both the concentration and size distribution of particles in flue gas by an on-line method. In particular, it is required to measure the particle size distribution of pulverized coal to control combustion conditions of pulverized coal and the performance of a coal pulverizer.

In this research, an on-line measuring apparatus of both particle size distribution and concentration has been developed. This apparatus consists of three-stage classifiers and load cells to weigh the classified particles. The particle size distribution is calculated from cut sizes of the classifiers and weight fractions of the classified particles. The overall particle concentration is decided from the total weight of the collected particles and the total volume of induced gas. The particle size distributions calculated from this method are in fairly good agreement with the one measured by a conventional light diffraction method.

\footnotetext{
Key Words : Particle Size Distribution, On-line Measurement,

Three Stage Classification, Isokinetic Sampling, Cyclone, Louver
}

\section{1. 緒 言}

気流中粒子のオンライン粒度計測は, 粉砕機器の性 能評価, 反応装置の運転管理などにおいて極めて重要 である。特に, 石炭火力発電所における, ボイラ一入 口部の微粉炭の粒度の測定は, ミルの性能管理および

\section{4年 9月 7日受付}

化学工学会米沢大会(1990年7月米沢)にて一部発表

* (財)電力中央研究所横須賀研究所

( 解 $240-01$ 横須賀市長坂 2-6-1)

TEL. $0468-56-2121$

**三協パイオテク(株)

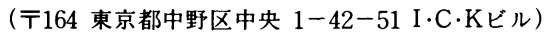

TEL. 03-3227-2011

**（社）日本粉体工業技術協会

( (606 京都市左京区田中関田町 27 思文閣会館)

TEL. $075-751-0195,761-7123$
火炉での燃焼管理の上で重要な操作となっている。

これまで, 種々の原理に基づくオンライン粒度測定 装置が提案されてきだ”゙，実ボイラーで使用されて いる例はあまり多くない。近年, レーザ一回折式の粒 度分布測定装置が広く用いられるようになり, それを オンライン計測に利用する方式もあるが, 測定試料を サンプリングして少量にする必要があり, 縮分操作を も自動で実施しなければならないため, 実用化するに

$†$ Central Res. Inst. of Electric Power Industry, Yokosuka Res. Lab.,

(2-6-1, Nagasaka, Yokosuka-shi, Kanagawa 240-01)

†† Sankyo Pio-Tech Co., Ltd. I C C.K Bldg. 42-5 Chuo 1chome, Nakano-ku Tokyo, 164)

†t† The Assoc. of Powder Process Industry and Eng., Japan. (Shibunkaku-Kaikan, 2-7, Tanakasekiden-cho, Sakyo-ku, Kyoto, 606) 
はかなりの困難が伴う。

筆者らは，分級径の異なる分級器を直列に複数段設 置し，その捕集量を自動的に計量することで粒度分布 を求める三段分級式粒度分布測定器を考案し, その性 能を基礎実験により評価検討した。さらに，本装置と 固気二相流の圧力損失から気体流量と粉体流量の測定 を行う差圧式粉体流量計 ${ }^{2}$ (商品名：ニューマライン

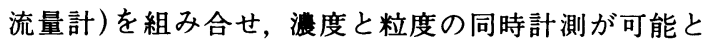
なる浱度・粒度自動測定装置を製作し，実ボイラーへ の適用を試みた。

本文では, 開発した気流中湿度・粒度自動計測装置 の構造，および測定精度の検討結果を述べると共に， 実際の石炭火力への適用例を報告する。

\section{2. 三段分級式粒度分布測定器の基本概念}

本粒度分布測定器は, 分級径の異なる 3 つの分級器 を直列に接続している。各分級器の分級径が既知であ れば，それらの粗粉収率より各分級径 $\left(D_{\mathrm{pc}}\right)$ に対する 累積ふるい上重量割合 $(R)$ を求めることができる。粗 粉収率を求めるにあたっては, 各分級器の粗粉採取量 と最終段も通過した微粉捕集用サイクロンの採取量と を自動で計量し，その総和から収率を計算する方法を 用いた。

本方式は, 通常の分級式粒度分布測定器に比べ三段 と分級段が少ないが，一般に粉砕物の粒度はRosinRammler分布に従うと言われているので，3点の分級 径に対する累積ふるい上重量割合が測定できれば，そ れを基に最小自乗法による直線近似を行い，50\%径 $D_{\mathrm{p} 50}$ と分布の勾配(均等数 $n$ )を求めることができる。

なお, 分級器の分級効率が余り高くなくても, 分級 径における真の微粉の粗粉側への混入量と真の粗粉の 微粉側への混入量がほぼ同一とみなされれば, 粒度分 布の推定には差し支えないので，この考え方が本法の 基礎となっている。

\section{3. 三段分級式粒度分布測定器の構造と性能}

試作した粒度分布測定装置の構成をFig. 1に示す。 測定粉体としては石炭火力発電所の微粉炭 $\left(D_{\mathrm{p} 50} \fallingdotseq 40\right.$ $\mu \mathrm{m})$ を主な対象とするため, 各分級器の分級径を約 70，30および10umとした。分級径の大きさの順にル 一バ分級器 ( I ) と (II)，およびサイクロン ( I )の三つ の分級器を用い, $10 \mu \mathrm{m}$ 以下のサイクロン ( I ) 通過粒 子をほぼ全量捕集するためのサイクロン（II）を最終段 に設置してある。

各分級器の粗粉粒子は各捕集ホッパー(7)に貯えら

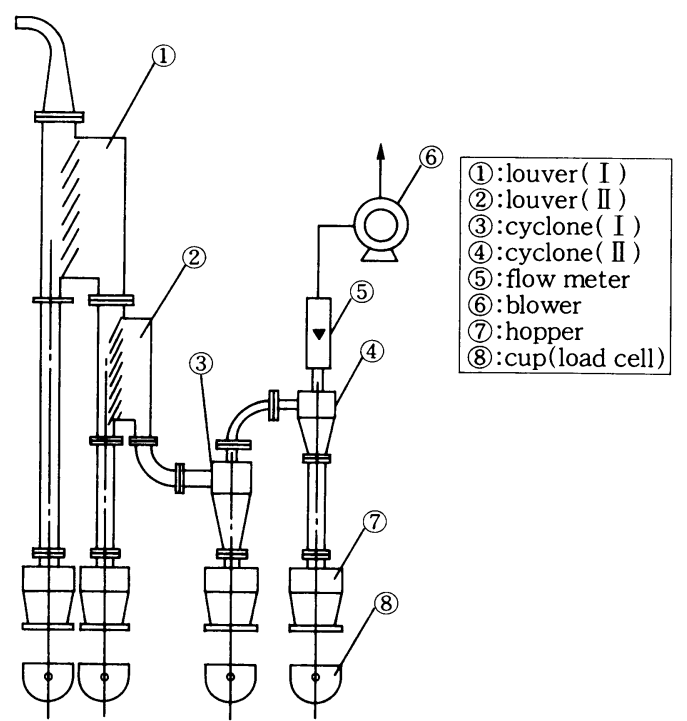

Fig. 1 Measuring apparatus of particle size distribution with three-stage classifiers

れ，サンプリング終了後ホッパー下部ゲートを開ロ し，捕集粒子は計量カップ(8)落ち，ロードセルによ り重量を測定する。その後カップは反転し，捕集粒子 を系外に取り出した後, ゲートおよびカップは元の状 態に復帰する。なお，必要なサンプリング周期に応じ て上記の一連の操作を正確に行うようマイコンにより 制御し, 各分及器の分離径と捕集重量から粒度分布が 計算される。

さらに，図には示してないが分級器壁および配管壁 への粒子付着防止用に，各分級器には空気式自動戟打 装置およびバイブレーター(1 箇所)が設置してある。 粒度分布測定器本体の大きさは試料回収部を含めて高 さ $1520 \mathrm{~mm}$ ，幅 $510 \mathrm{~mm}$ ，奥行き $660 \mathrm{~mm}$ である。

\section{1 ルーパー分級器の特性}

慣性集じん機として使用されてきたルーバーは，分 級器3)としても使用できる。ルーバーの設計手法につ いてはいまだ十分には確立されていないものの，宇敷 ら ${ }^{4,5)}$ はルーバー羽根列の設計基準を得ており，ここで はそれらの結果を参考にしてFig. 2のような片側ルー バーを設計・試作した。なお，図の表中でNは旸根段 数,Lは奥行きである。

Fig. 3は, ルーバー分級器 (I)について実験を行 い, 供試粉および粗粉の粒度分布を測定し, 粗粉収率 より部分分離効率を求めた結果を示したものである。 図中, $Q$ は吸引風量, $m$ は微粉炭㴤度である。供試粉 と粗粉の粒度分布測定にはレーザー回折式粒度分析計 (SK-LASER：セイシン企業製)を用い，部分分離効 

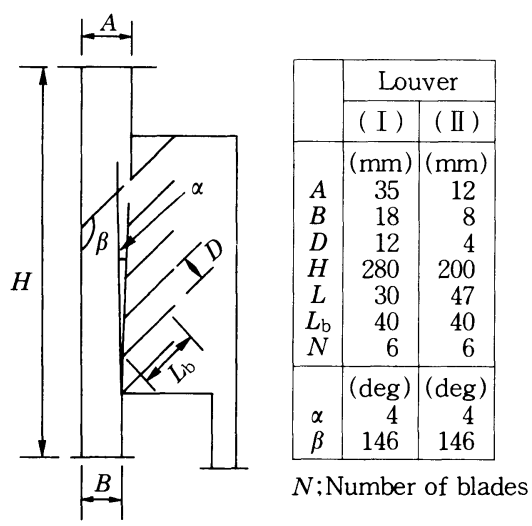

Fig. 2 Dimensions of louver classifiers

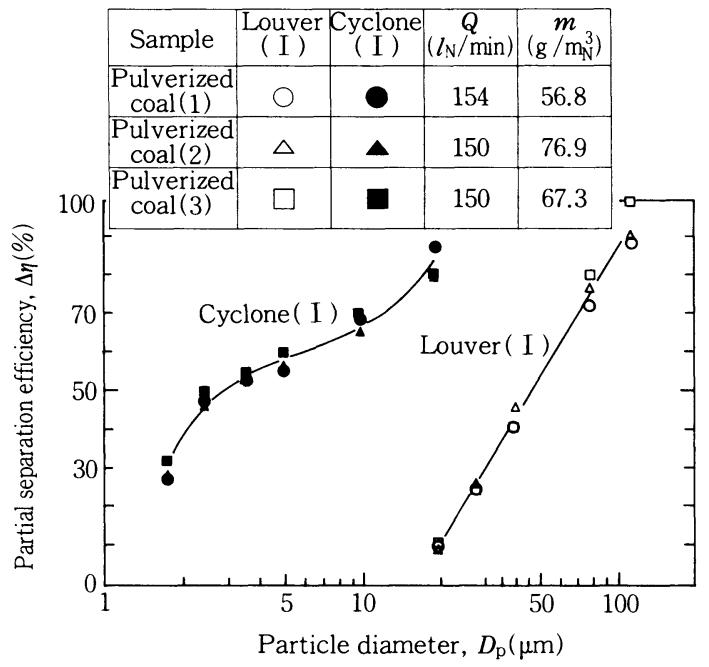

Fig. 3 Partial separation efficiencies of louver( I ) and cyclone( I )

率 $\Delta \eta$ は次式より求めた。

$$
\Delta \eta\left(\overline{D_{\mathrm{pi}}}\right)=\frac{\eta_{\mathrm{c}}\left\{R_{\mathrm{c}}\left(D_{\mathrm{pi}+1}\right)-R_{\mathrm{c}}\left(D_{\mathrm{pi}}\right)\right\}}{R_{0}\left(D_{\mathrm{pi}+1}\right)-R_{0}\left(D_{\mathrm{pi}}\right)}
$$

ただし

$$
\overline{D_{\mathrm{pi}}}=\sqrt{D_{\mathrm{pi}} D_{\mathrm{pi}}}
$$

ここで, $\eta_{\mathrm{c}}$ は粗粉収率, $R_{0}\left(D_{\mathrm{pi}}\right)$ と $R_{\mathrm{c}}\left(D_{\mathrm{pi}}\right)$ はそれぞれ

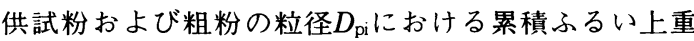
量割合である。Fig. 3は，粒度分布の異なる三種類の 微粉炭についての結果であるが, S.I. (Sharpness In$\operatorname{dex})=D_{\mathrm{p} 75} / D_{\mathrm{p} 25} \fallingdotseq 2.9$ となり, 分級の精度は高くな いが，供試粉の粒度分布が異なっても安定した分級が 行われており，粒度分布測定装置として用いるには十
分な性能を持つことがわかる。

一方，ルーバー（II）においては分級径を小さくする 必要があるため, 入口流速を増加し, 旸根間隔の小さ い構造となるよう ${ }^{3 \sim 5}$ Fig. 2に示す形状とした。

\section{2 サイクロン分級器の特性}

サイクロン（I）としては, Fig. 4の寸法比のものを 試作した。その部分分離効率をルーバーの場合と同様 にして求めた結果をFig. 3に示す。分級精度はあまり よくないが，異なる粒度を持つ粉体に対してもほぼ安 定した分級が行われることが明らかになった。

また，Fig.4には，本測定装置の最終段に設置した サイクロン（II）の寸法比をも示すが，捕集率は吸引風 量 $175 \times 10^{-3} \mathrm{~m}_{\mathrm{N}}^{3} / \min の$ 条件で，微粉炭供給量の $99.6 \%$ であり，充分実用になると考えられる。

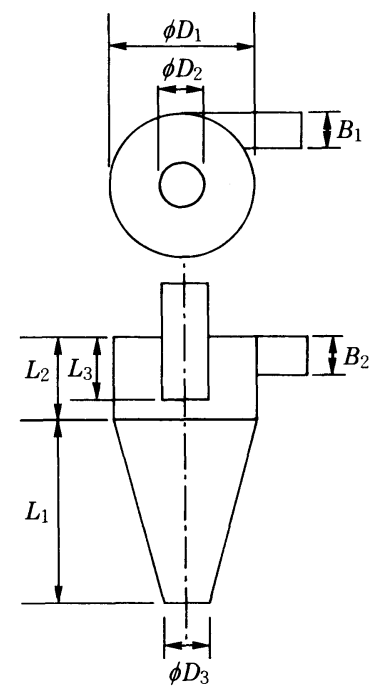

\begin{tabular}{|l|c|c|c|c|c|c|c|c|}
\hline & $L_{1}$ & $L_{2}$ & $L_{3}$ & $\phi D_{1}$ & $\phi D_{2}$ & $\phi D_{3}$ & $B_{1} \times B_{2}$ & \multicolumn{1}{c|}{ Remarks } \\
\hline Cyclone( I) & 105 & 80 & 110 & 50 & 30 & 15 & $14 \times 13$ & for classifier \\
\hline Cyclone ( I) & 120 & 25 & 30 & 50 & 15 & 18 & $\phi 15$ & for dust collector \\
\hline
\end{tabular}

Fig. 4 Dimens of cyclone classifier and final dust collector

\section{3 各分級器の分級径}

各分級器の分級径を決定するために，まず，小型の テーブルフィーダーから気流中に供給した粒径既知の 微粉炭(Coal(1))を回転旸根式の分散器で分散した後, 三段分級式粒度分布測定装置に導入し，各分級器で捕 集した微粉炭重量を測定した。この時の供給濃度 $m$ は $56.8 \mathrm{~g} / \mathrm{m}_{\mathrm{N}}^{3}$, 吸引風量は $Q=154 \times 10^{-3} \mathrm{~m}_{\mathrm{N}}^{3} / \mathrm{min}$ であ った。供試粉と各分級器での捕集粉の粒度分布を測定 した結果をFig. 5に示す。各捕集粉の50\%径はルーバ 一（Ｉ）より順番に $75 ， 49 ， 28 ， 8 \mu \mathrm{m}$ となっており，三 


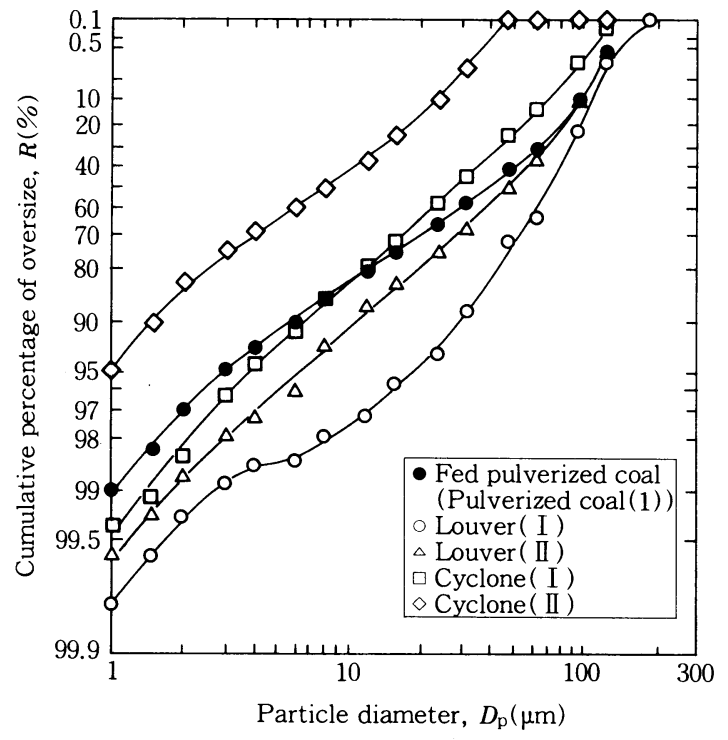

Fig. 5 Particle size distributions of classified pulverized coal(laser diffraction method)

段分級が確実に行われていることがわかる。その際の 各分級器の累積重量捕集率(Table 1) と供試粉の粒度 分布の測定結果とを用いて, Fig. 6に示すように各分 級器の分級径が求められる。Table 1には求められた

Table 1 Cumulative coarse fraction and cut size of classifiers

\begin{tabular}{l|c|c|c}
\hline Classifier & \multicolumn{2}{|c|}{$\begin{array}{c}\text { Cumulative coarse fraction } \\
R(\%)\end{array}$} & $\begin{array}{c}\text { Cut size } \\
D_{\mathrm{pc}}(\mu \mathrm{m})\end{array}$ \\
\hline \multirow{2}{*}{ Louver( I ) } & \begin{tabular}{c}
$(1) 40.2$ \\
\cline { 2 - 2 }
\end{tabular} & $\begin{array}{r}\text { average } \\
40.6\end{array}$ & 50 \\
\hline \multirow{2}{*}{ Louver( II ) } & $(1) 53.9$ & & \\
\cline { 2 - 2 } & $(2) 54.2$ & 53.8 & 31 \\
\hline \multirow{2}{*}{ Cyclone( I ) } & (1) 89.7 & & \\
\cline { 2 - 2 } & (2) 90.1 & 89.9 & 6 \\
\hline
\end{tabular}

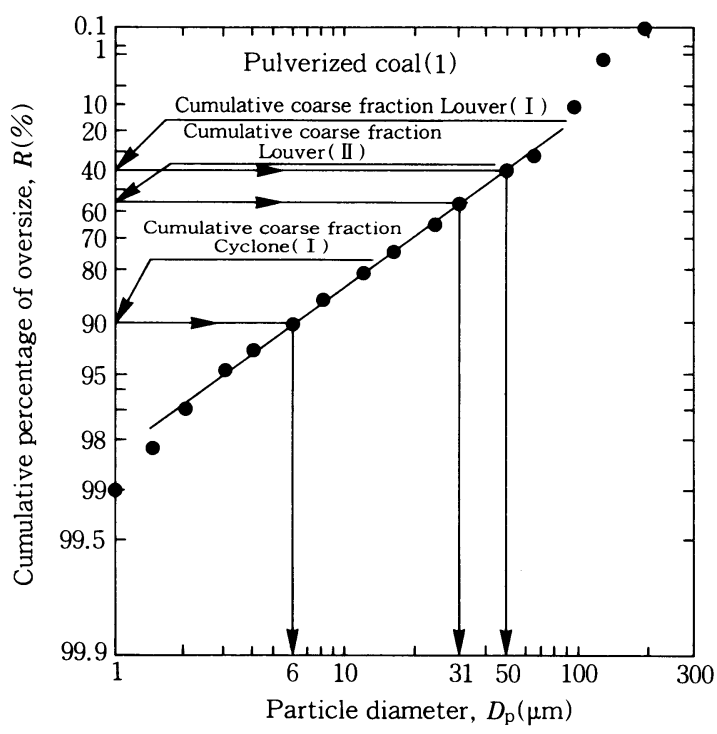

Fig. 6 Determination of cut sizes of classifiers 分級径をも示す。

本方式の測定精度を評価するため, 粒度分布の異な る 2 種類の微粉炭 $(\mathrm{Coal}(2)$, および(3)) を供試粉とし て粒度分布測定を実施した。実験結果をTable 2 およ びFig.7に示す。図示されるように, 試作した粒度分 布測定装置による結果と, レーザ一式粒度分析計によ る結果とは50\%径, 分布とも良好に一致し, 本装置は 粒度分布測定装置として十分, 使用可能であることが わかった。

\section{4 分級径に及ぼす吸引風吾および微粉炭漶度 の影望}

分級器は吸引風量や微粉炭濃度によって分級径が異 なる。これらの分級径に及ぼす影響の検討結果をFig. 8に示す。図より明らかなように分級径は風量と共に 大きくなり, 濃度が高ければ小さくなっている。この 結果を基に, 本実験範囲内における分級径 $\left(D_{\mathrm{pc}}\right)$ は次

Teble 2 Particle size distribution

\begin{tabular}{|c|c|c|c|c|c|c|c|}
\hline \multirow{2}{*}{ Sample } & \multicolumn{3}{|c|}{$\begin{array}{l}\text { Cumulative coarse fraction } \\
\qquad R(\%)\end{array}$} & \multicolumn{2}{|c|}{$\begin{array}{c}50 \% \text { particle diameter } \\
\qquad D_{\mathrm{p} 50}(\mu \mathrm{m})\end{array}$} & \multicolumn{2}{|c|}{$\begin{array}{c}\text { Constant of } \\
\text { Rosin-Rammler distribution } \\
n(-)\end{array}$} \\
\hline & Louver( I ) & Louver (II ) & Cyclone( I ) & $\begin{array}{l}\text { This } \\
\text { method }\end{array}$ & $\begin{array}{l}\text { Laser diff. } \\
\text { method }\end{array}$ & This method & $\begin{array}{l}\text { Laser diff. } \\
\text { method }\end{array}$ \\
\hline $\begin{array}{l}\text { Pulverized } \\
\text { coal (1) }\end{array}$ & 40.6 & 53.8 & 89.9 & 37 & 34 & 1.024 & 1.133 \\
\hline $\begin{array}{l}\text { Pulverized } \\
\text { coal( } 2 \text { ) }\end{array}$ & 47.8 & 63.0 & 92.7 & 46 & 45 & 1.034 & 1.079 \\
\hline $\begin{array}{l}\text { Pulverized } \\
\operatorname{coal}(3)\end{array}$ & 38.9 & 54.4 & 90.6 & 36 & 31 & 1.081 & 0.977 \\
\hline
\end{tabular}




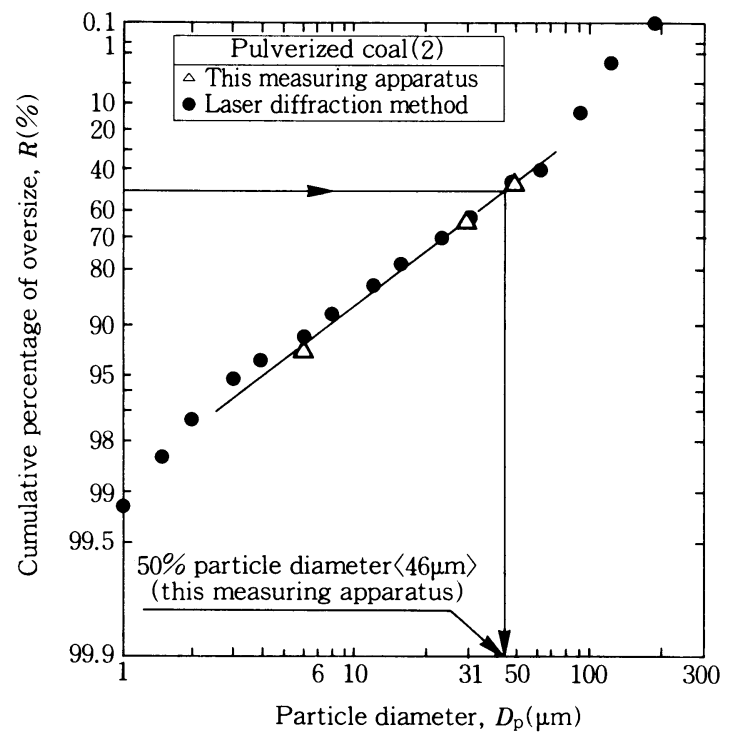

Fig. 7 Comparison of particle size distributions with this masuring apparatus and a laser diffraction method for pulverized coal(2)

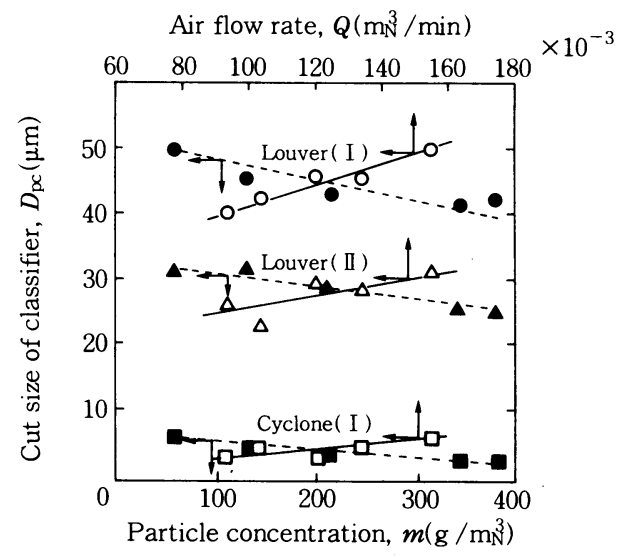

Fig. 8 Effects of air flow rate (white symbols) and particle concentration(black symbols) on cut size of the classifiers

式の形で整理される。

$$
D_{\mathrm{pc}}=a\left(\frac{Q}{Q_{0}}\right)^{b}\left(\frac{m}{m_{0}}\right)^{-c}
$$

ただし，分級径 $D_{\mathrm{pc}}(\mu \mathrm{m})$, 吸引風量 $Q=(93 \sim 154) \times$ $10^{-3} \mathrm{~m}_{\mathrm{N}}^{3} / \mathrm{min}$, 基準吸引風量 $Q_{0}=100 \times 10^{-3} \mathrm{~m}_{\mathrm{N}}^{3} / \mathrm{min}$,

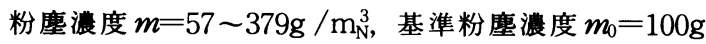
$/ \mathrm{m}_{\mathrm{N}}^{3}$ である。また $a, b, c$ は係数であり, Table 3に 各分級器の值を示す。これらの係数を用いてEq. (2) より分級径を求めた結果と,レーザ一回折法による測 定值から分級径を求めた結果との比較をするとFig.
Table 3 Coefficient $a, b, c$ in Eq. (2)

\begin{tabular}{l|c|c|c}
\hline \multirow{2}{*}{ Classifier } & \multicolumn{3}{|c}{ Coefficient } \\
\cline { 2 - 4 } & $a$ & $b$ & $c$ \\
\hline Louver( I ) & 39.8 & 0.396 & 0.094 \\
\hline Louver( II ) & 24.6 & 0.466 & 0.120 \\
\hline Cyclone( I ) & 3.56 & 0.777 & 0.512 \\
\hline
\end{tabular}

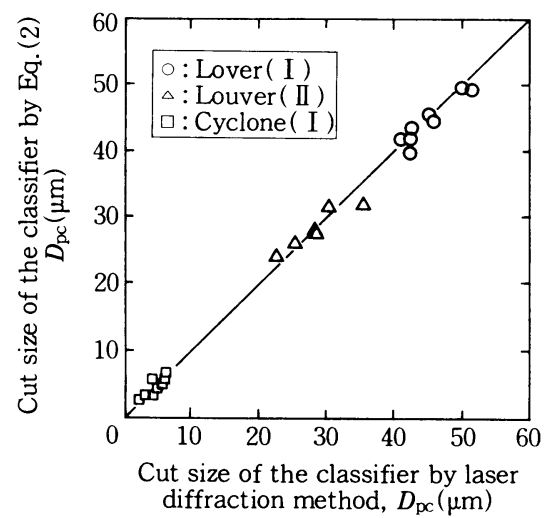

Fig. 9 Comparison of cut sizes of the classifiers by Eq. (2) and a laser diffraction method

9が得られ，ほぼ良好な相関関係が得られている。

\section{4. オンライン濃度・粒度自㲜測定装置の構成 と艺の性能}

上述のように，三段分級式粒度分布測定器の性能を 基礎実験で検討してほぼ良好な結果が得られたので, 差圧式粉体流量計と組み合せたオンライン溇度・粒度 自動測定装置を試作し，石炭ボイラーの燃料管で微粉 炭の測定を行った。試作したオンライン濃度・粒度自 動測定装置の構成図をFig. 10に示す。主な測定対象 である石炭火力の燃料管は直径 $300 \mathrm{~mm}$ 程度と非常に 大きいため, 図に示すように濃度・粒度の計測はサン プリング方式で実施した。サンプリング管は静圧平衡 型の内径 $\phi 11.4$ の等速吸引ノズルで, 静圧測定用の圧 カタップは内径 $\phi 2.0$ である。タップ取付け位置は, ズル内静圧測定用と燃料管内静圧測定用について, そ れぞれノズル先端から $5 \mathrm{~mm}$ おび $60 \mathrm{~mm}^{6}$ とした。圧 カタップの粒子による閉塞を防止するために, エアパ 一ジラインを設けてある。測定装置の前には, 等速吸 引用のコントロールバルブがあり，ノズル内外の静圧 が等しくなるようにマイコンで制御される。また，図 には示していないがサンプリングを行わないブロワー 停止中に，粒子が吸引ノズル内に飛び込んでくるのを 防ぐためのボールバルブが，ノズルのすぐ後に設けて 


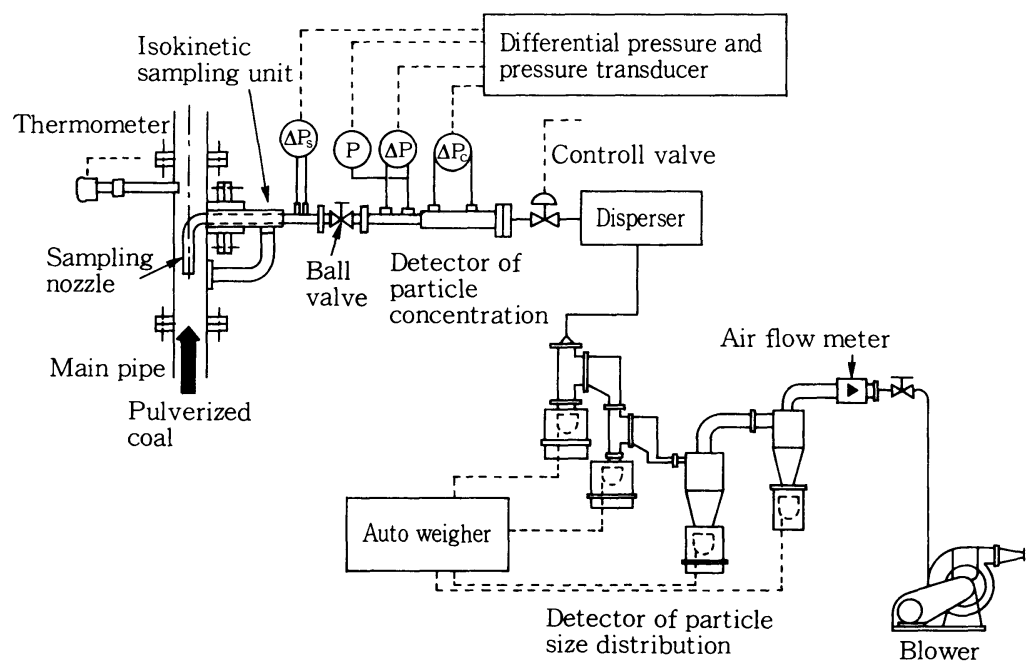

Fig. 10 Schematic diagram of the on-line measuring unit

ある。測定にあたっては所定の位置にノズルを設置し た後, ブロワーを駆動させるとともに，ノズル後のボ 一ルバルブを開けてサンプリングを開始する。コント ロールバルブにより等速吸引条件に設定した後, ブロ ワー前のロータメーターで吸引空気量を説み取る。所 定時間サンプリングを行った後にバルブを閉めると同 時にブロワを停止する。その後, 各分級器で捕集され た試料重量, 分級径, 累積ふるい上重量割合および50 \%平均粒子径がプリントアウトされる。なお, 微粉炭濃 度 $m$ は濃度検出器により瞬時值および経時変化が得 られ, 吸引風量, サンプリング時間および各分級器での 捕集総重量より測定時間内の濃度平均值が求められる。

また，搬送空気中に含まれる水分の凝縮による配管 系への微粉炭付着を防止するため, 粒度分布測定装置 本体をはじめ, 測定装置管路全体をリボンヒータで約 $60^{\circ} \mathrm{C}$ 前後に加温できる構造とした。この加温の分級径
に及ぼす影響は, 実験室の検討で室温から $60^{\circ} \mathrm{C}$ 範囲 ではほとんど認められなかったので，Eq. (2)において 温度補正は行わなかった。さらに，測定開始時におけ る吸引ノズルの内外の静圧が等しくなるまでの所要時 間は約 10 秒程度と短く，等速吸引の応答性は極めて良 好であった。

本試作装置を, 石炭火力発電所のボイラ然料管を流 れる実際の微粉炭の計測に用い, $\operatorname{Coal}(1),(2),(3)$ とは性状の異なる微粉炭に对する性能を検証した。 Table 4に, 本装置で計測した微粉炭の50\%径，およ びRosin-Rammler分布における均等数 $n$ の值と, レ 一ザー式粒度分析計で測定したそれらの值を比較した 結果の一例を計測条件とともに示し, Fig. 11には, $50 \%$ 径における本装置とレーザ式との測定值の比較を 示す。平均粒子径, 均等数共に, 両者の測定值には若 干のばらつきは見られるものの，ほぼ良好な一致が得

Teble 4 Particle size distribution obtained by this on-line measuring unit

\begin{tabular}{c|c|c|c|c|c}
\hline \multirow{2}{*}{$\begin{array}{c}\text { Air flow rate } \\
Q\end{array}$} & $\begin{array}{c}\text { Particle concentration } \\
m\end{array}$ & \multicolumn{2}{|c|}{$\begin{array}{c}50 \% \text { particle diameter } \\
D_{\mathrm{p} 50}(\mu \mathrm{m})\end{array}$} & \multicolumn{2}{c}{$\begin{array}{c}\text { Distribution constant } \\
n(-)\end{array}$} \\
\cline { 3 - 6 }$\left(\mathrm{m}_{\mathrm{N}}^{3} / \mathrm{min}\right)$ & $\left(\mathrm{g} / \mathrm{m}_{\mathrm{N}}^{3}\right)$ & 22.0 & 25.2 & 1.002 & 1.193 \\
& 138.1 & 29.0 & 23.9 & 1.045 & 1.139 \\
$140 \times 10^{-3}$ & 72.3 & 29.4 & 29.0 & 1.059 & 1.121 \\
$153 \times 10^{-3}$ & 81.3 & 30.3 & 33.2 & 1.078 & 1.183 \\
$134 \times 10^{-3}$ & 161.8 & 30.7 & 28.9 & 1.088 & 1.121 \\
$137 \times 10^{-3}$ & 94.6 & 31.3 & 36.6 & 1.145 & 1.159 \\
$135 \times 10^{-3}$ & 136.7 & 33.1 & 28.7 & 1.188 & 1.131 \\
$150 \times 10^{-3}$ & 79.7 & 69.3 & 39.7 & 0.898 & 1.092 \\
$154 \times 10^{-3}$ & 212.9 & 65.8 & 0.953 & 1.077 \\
$140 \times 10^{-3}$ & 541.7 & 73.4 & 76.4 & 1.062 & 1.100 \\
$122 \times 10^{-3}$ & 434.1 & & & & Laser diff. method \\
$142 \times 10^{-3}$ & & &
\end{tabular}




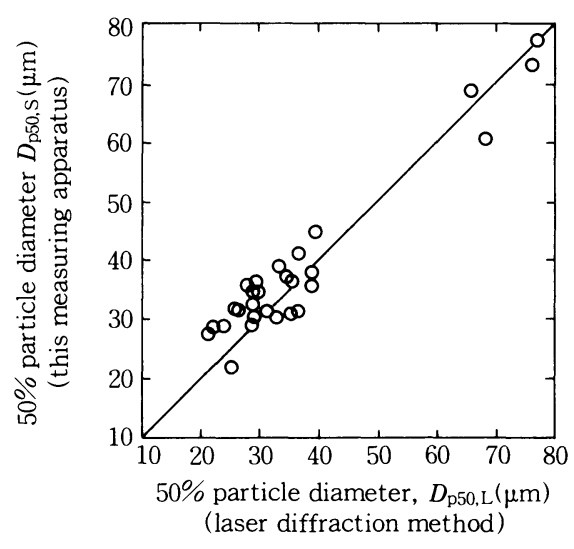

Fig. 11 Comparison of $50 \%$ particle diameters by a laser diffraction method and this on-line measuring apparatus

られている。

また, Fig. 12に3段の分級器および最終の全量捕 集用サイクロンで捕集した微粉炭の総重量から求めら れた粉体流量と, 連続監視用の差圧式粉体流量計で求 めた流量との関係を示す。差圧式粉体流量計の差圧か ら流量への変換のための検定はCoal(1)で行っている ため, 石炭銘柄が異なる実ボイラでは密度や粒径分布 が異なることから, 重量法と完全な一致がみられない。 しかし, 直線関係は良好であり, 粉体流量の経時変化 監視用としては充分な性能を有しているといえる。

以上の結果より, 開発した本測定装置はオンライン 用の粒度分布測定装置として十分使用できることが明 らかになった。

$a \quad$ : coefficient in Eq. (2)

$b \quad$ : coefficient in Eq. (2)

c : coefficient in Eq. (2)

$D_{\mathrm{p}} \quad$ : particle diameter

$D_{\mathrm{p} 50}$ : mean particle diameter

$D_{\mathrm{pc}}$ : cut size of classifier

$m$ : particle concentration

$m_{0}$ : standard particle concentration

$N \quad$ : number of louver blades

$n$ : distribution constant of the Rosin-Rammle

(m) $\left(\mathrm{kg} / \mathrm{mN}_{\mathrm{N}}^{3}\right)$ $\left(\mathrm{kg} / \mathrm{m}_{\mathrm{N}}^{3}\right)$

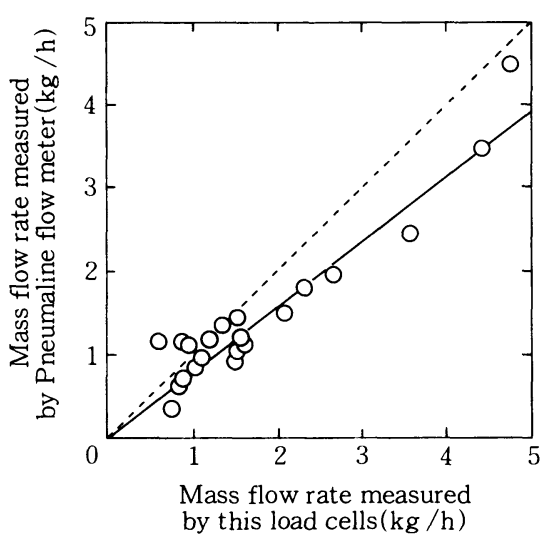

Fig. 12 Relation between powder mass flow rates measured by the Pneumaline and this load cell method

\section{5. 結 言}

三段分級式のオンライン粒度分布測定装置を試作 し, 微粉炭を対象に性能の検討を行い, 粒度分布測定 装置として十分な精度を有していることを明らかにす ると共に, 装置の操作条件が測定結果に及ぼす影響を 調べて, 幅広い使用条件でも正確な測定が行えること を明らかにした。

さらに, 本装置とニューマライン流量計を組み合わ せた濃度・粒度自動測定装置を製作し，実際の石炭火 力発電所ボイラ一入口部の燃料管内の微粉炭のオンラ イン濃度・粒度測定を行い, 実機での測定に十分適用 できることを明らかにした。

\section{Nomenclature}

(m) size distribution

(-) $\quad$ : gas flow rate

(-) $\quad Q_{0} \quad$ : standard gas flow rate

(m) $\quad R_{0} \quad$ : cumulative oversize fraction of feed particle

(m) $\quad R_{\mathrm{c}} \quad$ : cumulative oversize fraction of coarse particle

$\eta_{\mathrm{c}} \quad$ : total recovery of coarse particles

$\Delta \eta \quad$ : partial separation efficiency

\section{References}

1) Iinoya, K., H. Masuda and K. Watanabe ; Powder and Bulk Solid Handling Processes, Instrumentation and Control, p.151, Marcel Dekker, Inc., New York (1988)

2) Watanabe, K. and K. Saito ; Proc. of Intl. Conf. on Mechanics of Two-phase Flow, p.134, National Taiwan Univ., Taipei(1989)

3) Iinoya, K., N. Kimura and Z. Tanaka; J. Soc.
Powder Technol., Japan, 1, 114(1964)

4) Ushiki, K., Z. Tanaka and K. Iinoya ; Kagaku Kogaku, 38, 151(1974)

5) Ushiki, K., H. Sawada and K. Iinoya ; Kagaku Kogaku Ronbunshu, 5, 424(1974)

6) Chiba, T. and K. Hoshizawa ; The Thermal Power, 12, 49(1961) 